\title{
Keanekaragaman Jenis Ikan Di Perairan Mangrove Desa Pasir Kabupaten Mempawah Kalimantan
} Barat

\author{
Umar Faruk $^{1 *}$, Arie Antasari Kushadiwijayanto ${ }^{1}$, Ikha Safitri ${ }^{1}$ \\ 1 Program Studi Ilmu Kelautan, FMIPA, Universitas Tanjunpura, Pontianak- \\ Indonesia \\ *Correspondence email: Umar Faruk \\ $\bowtie$ umarfaruk.marinescience13@gmail.com
}

\author{
Received : 28 December 2018 - Accepted: 10 March 2019 \\ Published: 30 June 2019 @ Author(s) 2019. This article is open access
}

\begin{abstract}
Kabupaten Mempawah, Provinsi Kalimantan Barat, memiliki ekosistem mangrove buatan yang dapat mendukung tersedianya sumberdaya ikan. Penelitian ini bertujuan untuk mengobservasi keanekaragaman jenis ikan di ekosistem mangrove. sampel ikan ditangkap menggunakan gillnet dengan ukuran mata jaring 2, 2.5, dan 3 inci. Penelitian ini dilakukan di perairan mangrove Desa Pasir pada Agustus 2017. Pengumpulan sampel dilakukan pada lima stasiun pengambilan data, menggunakan metode purposive sampling. Total sampel yang didapatkan sebanyak 125 individu ikan untuk 12 famili dan 23 genus, dimana 18 genus telah teridentifikasi dan 5 lainnya belum teridentifikasi selama pengambilan data. Hasil identifikasi menunjukkan bahwa secara umum Coilia dan Larimichthys dapat ditemukan pada semua stasiun, dan Coilia yang memiliki kelimpahan tertinggi. Nilai untuk indeks keanekargaman $\left(\mathrm{H}^{\prime}\right)$ adalah sedang dengan rentang 1.75-2.52, indeks keseragaman (E) tinggi dengan rentang 0.90-0.94, dan indeks dominansi (C) rendah dengan rentang 0.09-0.20. Stasiun III memiliki keanekaragaman dan kelimpahan ikan tertinggi karena memiliki kerapatan vegetasi mangrove yang tinggi. sedangkan, stasiun yang memiliki kelimpahan ikan terendah ialah stasiun II dan V karena pengaruh aktivitas antropogenik.
\end{abstract}

Keywords: Keanekaragaman, jenis ikan, mangrove, kelimpahan, dominansia

\section{Pendahuluan}

Kalimantan Barat memiliki sumberdaya hayati laut cukup potensial, termasuk sumberdaya perikanan dan ekosistem pesisir, serta memiliki panjang garis pantai $1.398 \mathrm{~km}$, luas pesisir pantai 2.100 .000 ha, dan kawasan mangrove dan estuarine 482.386,8 ha (BPSPL, 2014). Kabupaten Mempawah sebagai daerah pesisir di Kalimantan Barat memiliki panjang garis pantai mencapai 120 $\mathrm{km}$ dan seluruhnya relatif rawan abrasi. Selama 20 tahun terakhir, pantai di
Mempawah hilang sekitar 1,5 km (Kamsari, 2015). Kabupaten Mempawah juga memiliki luasan hutan mangrove yang rawan abrasi terbukti dalam kurun waktu 25 tahun terakhir mangrove mengalami degradasi seluas $250,11 \mathrm{Ha}$, luas mangrove yang tersisa hanya 739,31 Ha ditahun 2014 (Khairuddin et al., 2015).

Mangrove merupakan salah satu dari beberapa ekosistem pesisir yang dapat menyediakan layanan untuk kepentingan manusia. Ekosistem mangrove memiliki produktivitas yang tinggi dan daya dukung 
kehidupan laut khususnya organisme akuatik (Islam and Haque, 2004). Mangrove secara biologi menyediakan tempat tinggal untuk ikan dan organisme akuatik lainnya (Barbier, 2003; Lee, 2004; Islam and Haque, 2004; Harahab, 2009; Saenger et al., 2013), serta sebagai habitat ikan-ikan demersal (Barbier, 2000). Ekosistem mangrove juga berfungsi sebagai feeding ground (Islam and Haque, 2004; Nagelkerken et al., 2008; Hutchison et al., 2014; Nanjo et al., 2014; Rangkuti et al., 2017), nursery area (Barbier, 2003; Manson et al., 2005; Allen et al., 2012; Rangkuti et al., 2017), dan spawning ground (Hutchison et al., 2014; Nanjo et al., 2014; Rangkuti et al., 2017; Sihombing et al., 2017), serta sebagai tempat berlindung dari predator (Nagelkerken et al., 2008).

Ekosistem mangrove diketahui dapat mendukung sumberdaya dan pelayanan dengan total nilai ekonomis mencapai US\$ 194.000/ha/tahun. Ekosistem mangrove secara signifikan mendukung $10-30 \%$ dari total perikanan diseluruh dunia (Aburto-Oropeza et al., 2008; Costanza et al., 2014; Anneboina and Kumar, 2017). Mangrove sebagai ekosistem penyedia sumberdaya perikanan dan juga berperan penting untuk kegiatan perikanan yang berkelanjutan. Dalam hal itu, ada tiga faktor yang saling berinteraksi yaitu biota akuatik, habitat, dan manusia sebagai konsumen (Lackey, 2005).

Mangrove juga mendukung keanekaragaman flora, fauna laut dan pesisir (Hwanhlem et al., 2014; Lee et al., 2014). Dalam ekosistem mangrove, terdapat rantai makanan yang secara langsung atau tidak langsung memberikan kontribusi signifikan terhadap perekrutan ikan laut dewasa dan $80 \%$ dari ikan komersial yang ditangkap di perairan pantai sekitarnya (Harahab, 2009; Camp et al., 2011; Sandilyan and Katherisan, 2012). Mangrove dapat menyediakan manfaat ekologi dan ekonomi pada daerah pesisir, estuari, dan daerah tropis (Chowdhury et al., 2010) sehingga penting dalam menjaga mangrove sebagai habitat bagi berbagai jenis organisme akuatik.

Penelitian mengkaji karakteristik, kelimpahan, dan keanekaragaman ikan di ekosistem mangrove dapat digunakan sebagai indikator potensi produktivitas sumberdaya perikanan. Oleh karena itu, penting dilakukan penelitian mengenai keanekaragaman jenis ikan di perairan mangrove Desa Pasir Kabupaten Mempawah Kalimantan Barat. Rumusan masalah dari penelitian ini adalah bagaimana keanekaragaman jenis ikan di perairan mangrove Desa Pasir Kabupaten Mempawah. Manfaat dari penelitian ini untuk memberikan informasi awal mengenai keanekaragaman jenis ikan serta menjadi bahan kajian lebih lanjut dalam pengelolaan dan pemanfaatan ekosistem pesisir yang berkelanjutan di perairan Desa Pasir, Kabupaten Mempawah, Kalimantan Barat.

\section{Metode}

Pengambilan sampel dilaksanakan pada 19-21 Agustus 2017, di Desa Pasir Kabupaten Mempawah, Kalimantan Barat (Gambar 1). Stasiun sampling ditentukan

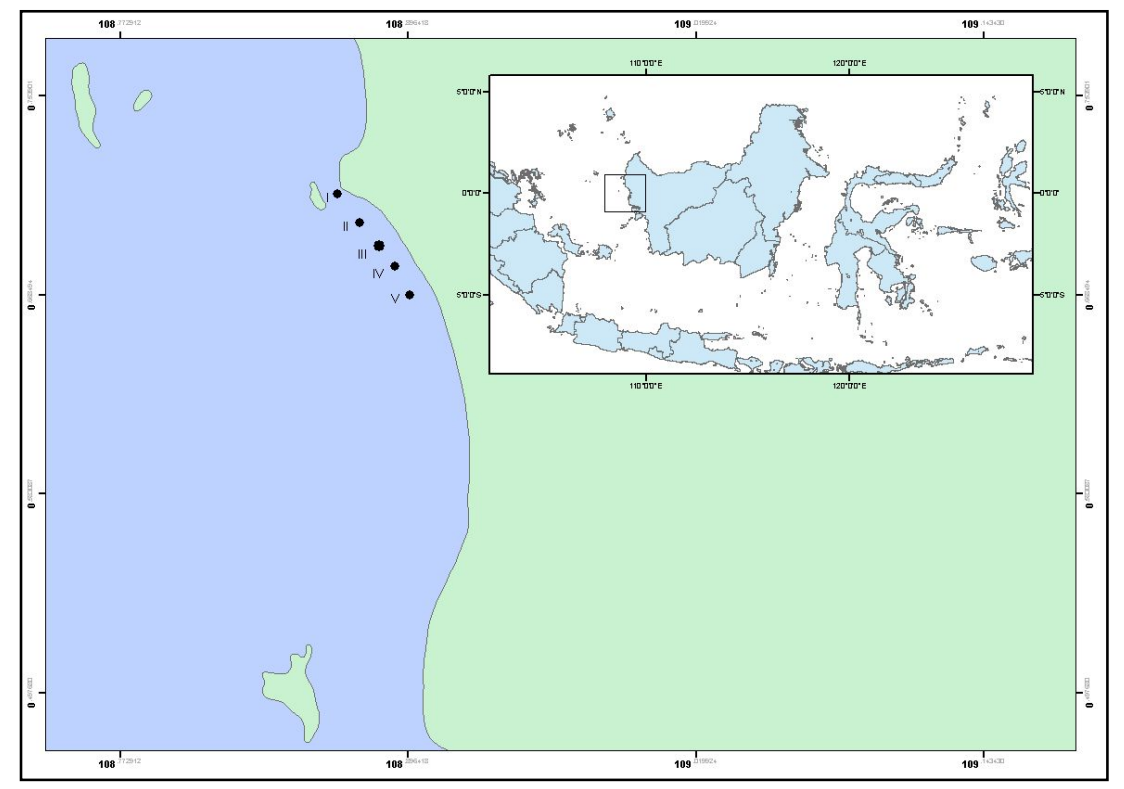

Gambar 1. Peta lokasi stasiun penelitian. Pengambilan sampel dilakukan di lima stasiun 
menggunakan metode purposive sampling yang terdiri atas 5 stasiun dengan jarak antar stasiun \pm 400 meter. Prinsip penentuan stasiun ini didasarkan pada keterwakilan lokasi penelitian. Sampel ikan diambil menggunakan alat tangkap gill net dengan ukuran mata jaring 2-2,5 dan 3 inchi. Parameter kualias air yang diambil adalah suhu, salinitas, $\mathrm{pH}$, dan DO.

Analisis data indeks keanekaragaman $\left(\mathrm{H}^{\prime}\right)$ ikan dapat di analisis menggunakan persamaan Shannon-Wiener (Odum,1993).

$$
H^{\prime}=-\sum\left(\frac{n_{i}}{N}\right) \ln \left(\frac{n_{i}}{n}\right)
$$

Dimana ni adalah jumlah individu setiap jenis, $\mathrm{N}$ adalah jumlah individu seluruh jenis. Tingkat keanekaragaman dinilai rendah apabila nilai $\mathrm{H}^{\prime}<1$, keanekaragaman sedang apabila $1<\mathrm{H}^{\prime}<3$, dan keanekaragaman tinggi apabila $H^{\prime}>3$. (Odum, 1993)

Indeks keseragaman (E) dihitung dengan menggunakan rumus Evenness Indek (Odum, 1993)

$$
E=\frac{H^{1}}{\ln S}
$$

Dimana $S$ adalah jumlah jenis organisme. Indeks keseragaman berkisar antara 0-1. Nilai E mendekati 0 maka sebaran individu antar jenis tidak seragam dan terjadi dominasi suatu jenis, dan apabila nilai E mendekati 1, maka sebaran individu antar jenis seragam.

Indeks dominansi (C) dihitung dengan rumus indeks (Odum, 1993).

$$
C=\sum\left(\frac{n_{i}}{N}\right)^{2}
$$

Kriteria Indeks Dominansi (C) dapat uditentukan dengan ketentuan: apabila $\mathrm{C}<0,50$ maka dominansi rendah; $0,50<\mathrm{C}<0,75$ dominansi sedang; dan $\mathrm{C}>0,75$ ominansi tinggi (Odum, 1993).

Kelimpahan relatif (KR) dihitung dengan menggunakan rumus (Krebs, 1989).

$$
K R=\frac{n_{i}}{N} \times 100 \%
$$

\section{Hasil dan Pembahasan}

\subsection{Kondisi Umum Lokasi Penelitian}

Lokasi penelitian terletak di Desa Pasir Kabupaten Mempawah Kalimantan Barat. Penelitian dilakukan di perairan mangrove hasil rehabilitasi yang memiliki luasan mangrove sekitar 739,31 ha di tahun 2014 (Khairuddin et al., 2015). Jenis mangrove yang tumbuh di perairan Desa Pasir adalah Avicennia sp. dan Rhizophora sp., tetapi secara umum lebih banyak ditumbuhi mangrove jenis Avicennia sp.

Lokasi sampling ikan dan parameter lingkungan dilakukan di lima stasiun. Stasiun I dan II mewakili daerah perairan mangrove yang dipengaruhi oleh aktifitas manusia, yaitu masing-masing berhadapan langsung dengan daerah wisata dan dermaga akses keluar masuknya kapal, akan tetapi aktifitas perkapalan lebih banyak pada stasiun II. Stasiun I dan II meupakan perairan semi tertutup karena terlindung oleh Pulau Penibung. Stasiun III mewakili daerah yang dipegaruhi aktifitas manusia berupa daerah penangkapan udang oleh nelayan, sedangkan stasiun IV mewakili daerah yang sama sekali tidak dipengaruhi oleh aktifitas manusia, dan stasiun V mewakili daerah yang dekat dengan kanal yang relaif lebih besar sebagai akses keluar masuknya kapal nelayan Desa Benteng. Semua stasiun umumnya ditumbuhi oleh mangrove jenis Avicennia sp. dan Rhizophora sp. kecuali stasiun IV dan V yang lebih banyak ditumbuhi mangrove jenis Avicennia sp. dengan tipe substrat lumpur.

Suhu air di perairan mangrove Desa Pasir berkisar antara 29,02-31 ${ }^{\circ} \mathrm{C}$. Suhu tersebut cocok untuk kehidupan mangrove dan organisme akuatik karena suhu masuk kedalam nilai standar dari Kementerian Lingkungan Hidup No. 51 Tahun 2004. Hal ini berarti bahwa suhu tersebut mendukung kehidupan semua organisme di ekosistem

Tabel 1. Parameter fisika-kimia perairan pada stasiun pengambilan data

\begin{tabular}{llccccc}
\hline Parameter & Standar & St I & St II & St III & St IV & St V \\
\hline Temperature $\left({ }^{\circ} \mathrm{C}\right)$ & $28-32$ & 29,02 & 29,42 & 30,32 & 30,68 & 31 \\
Salinitas $(\mathrm{ppt})$ & Max 30 & 27,5 & 27,25 & 28,25 & 27,83 & 28,5 \\
$\mathrm{pH}$ & $6,5-8,5$ & 8 & 8 & 8,26 & 8,34 & 8,30 \\
Oksigen terlarut $(\mathrm{ppm})$ & $>5$ & 2,76 & 2,12 & 1,813 & 1,84 & 1,913 \\
\hline
\end{tabular}


Tabel 2. Komposisi jenis ikan di perairan mangrove Desa Pasir

\begin{tabular}{|c|c|c|c|c|c|c|}
\hline Family & Genus & St I & St II & St III & St IV & St V \\
\hline \multirow{2}{*}{ Ariidae } & $\begin{array}{l}\text { Carlarius } \\
\text { (Duri udang) }\end{array}$ & 1 & 0 & 0 & 0 & 0 \\
\hline & $\begin{array}{l}\text { Sciades } \\
\text { (Belukang) }\end{array}$ & 1 & 0 & 1 & 0 & 1 \\
\hline Bagridae & $\begin{array}{l}\text { Sperata } \\
\text { (Duri udang) }\end{array}$ & 1 & 0 & 1 & 1 & 1 \\
\hline \multirow{2}{*}{ Clupeidae } & $\begin{array}{l}\text { Anodontostoma } \\
\text { (Selangat) }\end{array}$ & 2 & 0 & 1 & 4 & 0 \\
\hline & $\begin{array}{l}\text { Herklotsichthys } \\
\text { (Puput) }\end{array}$ & 2 & 0 & 0 & 2 & 0 \\
\hline Echeneidae & $\begin{array}{l}\text { Naucrates } \\
\text { (Manyuk sabun) }\end{array}$ & 1 & 0 & 0 & 0 & 0 \\
\hline \multirow{3}{*}{ Engraulidae } & $\begin{array}{l}\text { Coilia } \\
\text { (Gonjeng) }\end{array}$ & 4 & 7 & 4 & 4 & 2 \\
\hline & $\begin{array}{l}\text { Thryssa } \\
\text { (Biji nangka) }\end{array}$ & 2 & 0 & 3 & 5 & 1 \\
\hline & $\begin{array}{l}\text { Stolephorus } \\
\text { (Bulu ayam) }\end{array}$ & 0 & 4 & 2 & 2 & 4 \\
\hline Mugilidae & $\begin{array}{l}\text { Mugil } \\
\text { (Belanak) }\end{array}$ & 0 & 2 & 6 & 0 & 3 \\
\hline Muraeneocidae & $\begin{array}{l}\text { Congresox } \\
\text { (Malong) }\end{array}$ & 0 & 0 & 2 & 2 & 0 \\
\hline \multirow{2}{*}{ Sciaenidae } & $\begin{array}{l}\text { Johnius } \\
\text { (Gelame papan) }\end{array}$ & 4 & 0 & 2 & 3 & 2 \\
\hline & $\begin{array}{l}\text { Larimichthys } \\
\text { (Gelame torak) }\end{array}$ & 4 & 3 & 3 & 2 & 1 \\
\hline \multirow{2}{*}{ Scombridae } & $\begin{array}{l}\text { Grammatorcynus } \\
\text { (Tenggiri) }\end{array}$ & 0 & 0 & 1 & 0 & 0 \\
\hline & $\begin{array}{l}\text { Rastrelliger } \\
\text { (Manyuk madu) }\end{array}$ & 1 & 3 & 0 & 0 & 0 \\
\hline Stromateidae & $\begin{array}{l}\text { Stromateus } \\
\text { (Peda-peda) }\end{array}$ & 0 & 1 & 1 & 1 & 0 \\
\hline Tetraodontidae & $\begin{array}{l}\text { Dichotomyctere } \\
\text { (Buntal pisang) }\end{array}$ & 3 & 0 & 1 & 0 & 0 \\
\hline \multirow[t]{7}{*}{ Trichiuridae } & $\begin{array}{l}\text { Eupleurogrammus } \\
\text { (Timah-timah) }\end{array}$ & 1 & 0 & 0 & 1 & 0 \\
\hline & Bawal ubur-ubur & 0 & 1 & 0 & 0 & 0 \\
\hline & Bawal hitam & 0 & 0 & 1 & 0 & 0 \\
\hline & Kanghe & 0 & 0 & 3 & 0 & 0 \\
\hline & Kepetek lendir & 0 & 0 & 0 & 1 & 0 \\
\hline & Selangat padi & 0 & 0 & 0 & 0 & 2 \\
\hline & OTAL & 27 & 21 & 32 & 28 & 17 \\
\hline
\end{tabular}

mangrove Desa Pasir. Suhu merupakan salah satu faktor utama yang mempengaruhi proses kehidupan dan penyebaran organisme laut (Burhanuddin, 2011; Brahmana, 2014). Organisme akuatik memiliki kisaran suhu tertentu yang optimal bagi pertumbuhannya karena semakin tinggi suhu air, maka semakin sedikit oksigen yang terkandung di dalamnya (Effendi, 2003; Retnowati, 2011).
Salinitas di daerah penelitian memiliki nilai antara $27,25-28,5 \mathrm{ppt}$ dan tidak terlalu bervariasi antar stasiun. Nilai ini masih sesuai dengan standar salinitas yang ditetapkan oleh Kementerian Lingkungan Hidup No. 51 Tahun 2004. Hal ini berarti salinitas di perairan mangrove Desa Pasir sesuai untuk mendukung kehidupan organisme akuatik di perairan ekosistem 


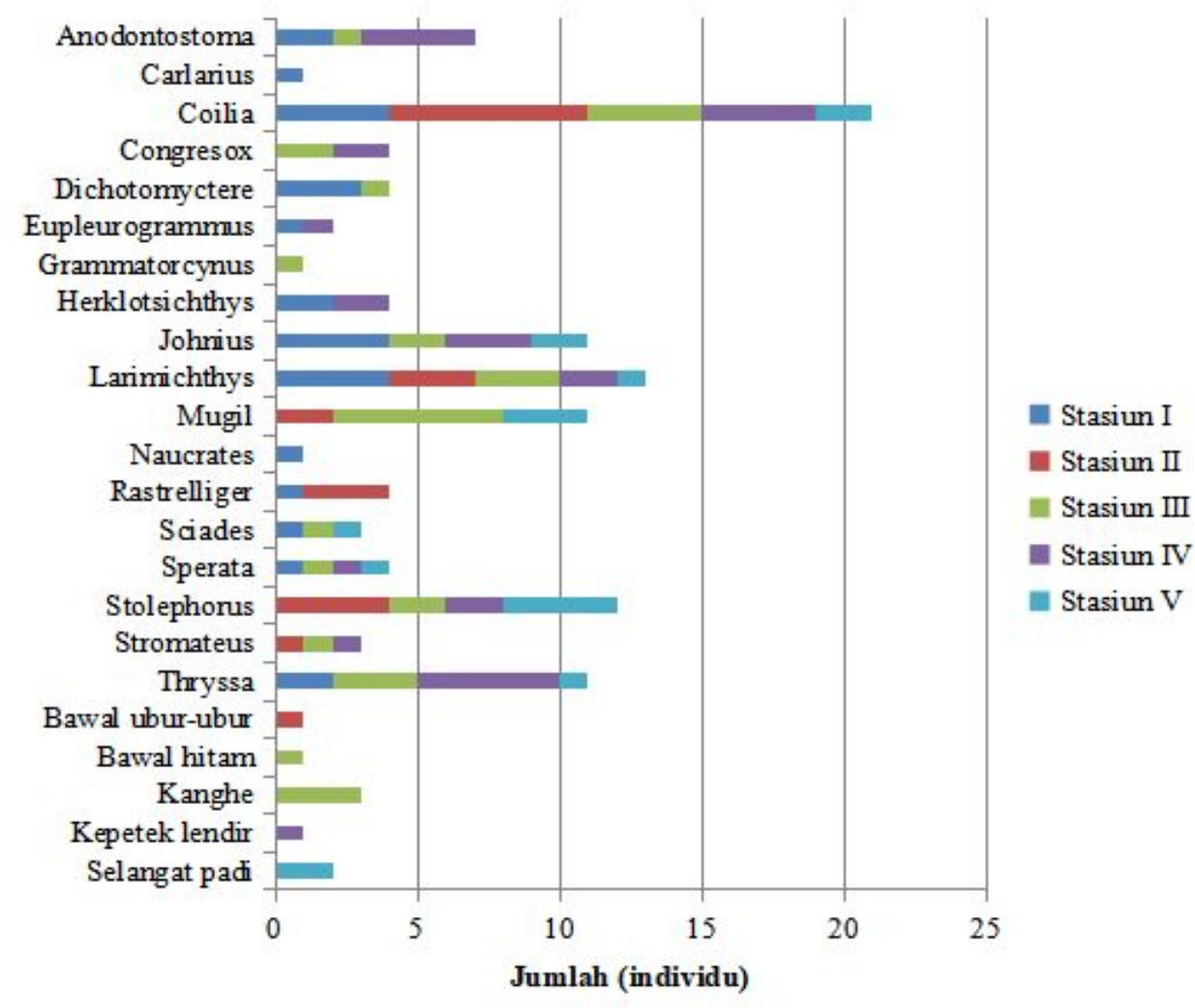

Gambar 2. Jenis-jenis ikan di perairan mangrove Desa Pasir Kabupaten Mempawah

mangrove. Secara umum, kebanyakan ikan yang hidup di ekosistem mangrove memiliki toleransi yang tinggi pada perubahan salinitas (McAllister et al., 2001; Chowdhury et al., 2010). Kelimpahan ikan bervariasi dengan fluktuasi salinitas (Hoque et al., 2015). Khalaf-Allah et al. (2014) menyebutkan bahwa salinitas merupakan salah satu faktor penting yang mempengaruhi komposisi, disribusi, dan keanekaragaman fauna di berbagai ekosistem akuatik, termasuk ekosistem mangrove.
Tingkat keasaman $(\mathrm{pH})$ perairan berkisar antara 8-8,34, yang berarti perairan tersebut dalam kondisi basa. Nilai $\mathrm{pH}$ ini masih cocok untuk kehidupan organisme akuatik di ekosistem mangrove, karena standar $\mathrm{pH}$ adalah 6,5-8,5 untuk air payau dan air laut. Kisaran $\mathrm{pH}$ antara 6,0-9,0 masih ditoleransi oleh organisme akuatik untuk mendukung pertumbuhannya (Wantasen, 2013). Perairan dengan nilai $\mathrm{pH}<6.5$ dan $>9.0$ tidak cocok untuk pertumbuhan organisme (Boyd, 2000; Rosli et al., 2010). Descasari et al. (2016),

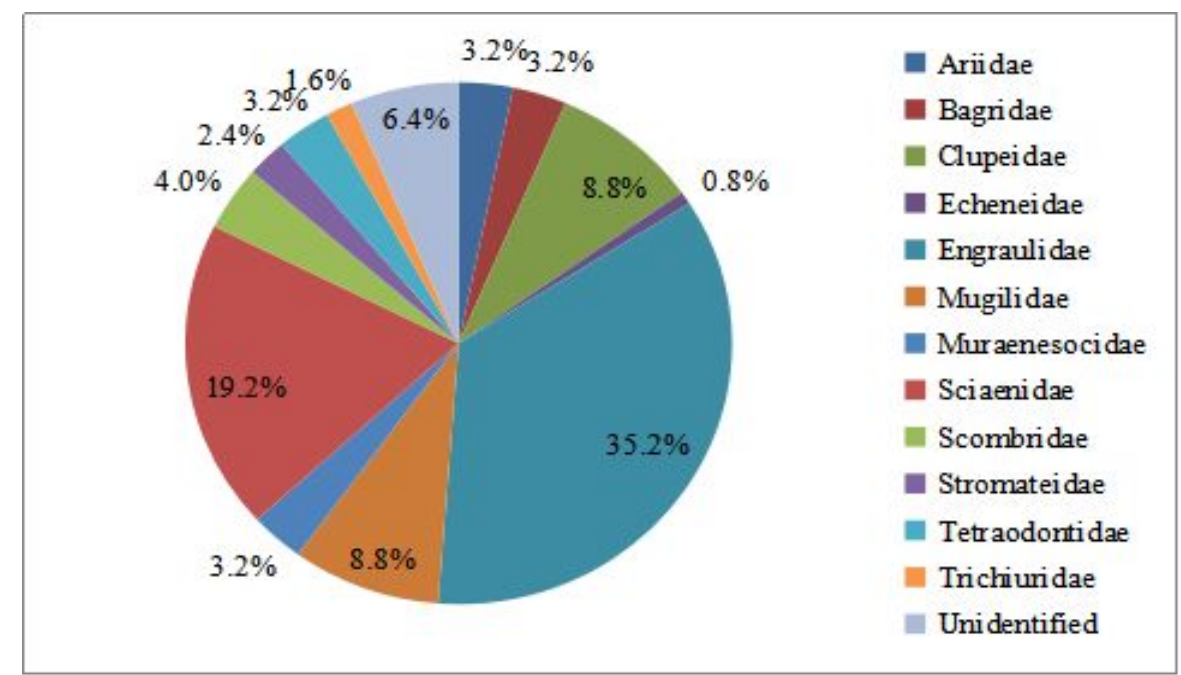

Gambar 3. Persentase jumlah famili di perairan mangrove Desa Pasir 
mengatakan bahwa derajat keasaman $(\mathrm{pH})$ merupakan faktor penting bagi biota akuatik, dan dapat menentukan kelimpahan dari organisme akuatik khususnya ikan (Novotny and Olem, 1994).

Oksigen terlarut (DO) di perairan mangrove Desa Pasir berkisar antara 1,81-2,76 ppm. Nilai DO perairan yang ditetapkan oleh Kementerian Lingkungan Hidup No. 51 Tahun 2004 yaitu $>5$ ppm. Oksigen terlarut merupakan salah satu unsur pokok untuk proses metabolisme organisme terutama untuk proses respirasi. Oksigen terlarut di perairan berasal dari hasil fotosintesis dan difusi langsung dari udara, kedalaman suatu perairan juga berpengaruh terhadap kadar oksigen terlarut (Odum, 1993). Selain itu, oksigen terlarut juga dapat digunakan sebagai petunjuk kualitas suatu perairan.

\subsection{Komposisi Jenis Ikan di Perairan}

\section{Desa Pasir Kabupaten Mempawah}

Komposisi jenis ikan pada masing-masing stasiun pengambilan data di perairan Desa Pasir Kabupaten Mempawah dapat ditunjukkan pada Gambar 2 dan Tabel 2 Berdasarkan hasil penelitian, ditemukan ikan dengan jumlah total 125 individu yang tergolong dalam 28 genus (teridentifikasi dan tidak teridentifikasi).

Genus ikan yang ditemukan dengan jumlah terbanyak pada stasiun I adalah Coilia, Johnius dan Larimichthys pada stasiun II yaitu genus Coilia dan Stolephorus, stasiun III yaitu genus Coilia dan Mugil, stasiun IV yaitu genus Coilia dan Thryssa, dan stasiun V yaitu genus Coilia dan Mugil. Stasiun yang memiliki hasil tangkapan ikan tertinggi adalah stasiun III (32 individu), sedangkan stasiun yang memiliki hasil tangkapan ikan terendah adalah stasiun V (17 individu). Hal tersebut dikarenakan pada stasiun III ditumbuhi oleh campuran mangrove Avicennia sp. dan Rhizophora sp., sedangkan pada stasiun $\mathrm{V}$ hanya ditumbuhi mangrove jenis Avicennia sp. Redjeki (2013), menyatakan bahwa kelimpahan dan keragaman jenis ikan pada perairan yang bervegetasi Rhizophora sp. lebih tinggi dibandingkan keragaman jenis ikan pada ekosistem yang bervegetasi Cyperus $s p$. (semak). Hutan mangrove yang didominasi Rhizophora apiculata merupakan habitat yang baik untuk sumberdaya perikanan. Hal ini disebabkan karena kompleksnya sistem

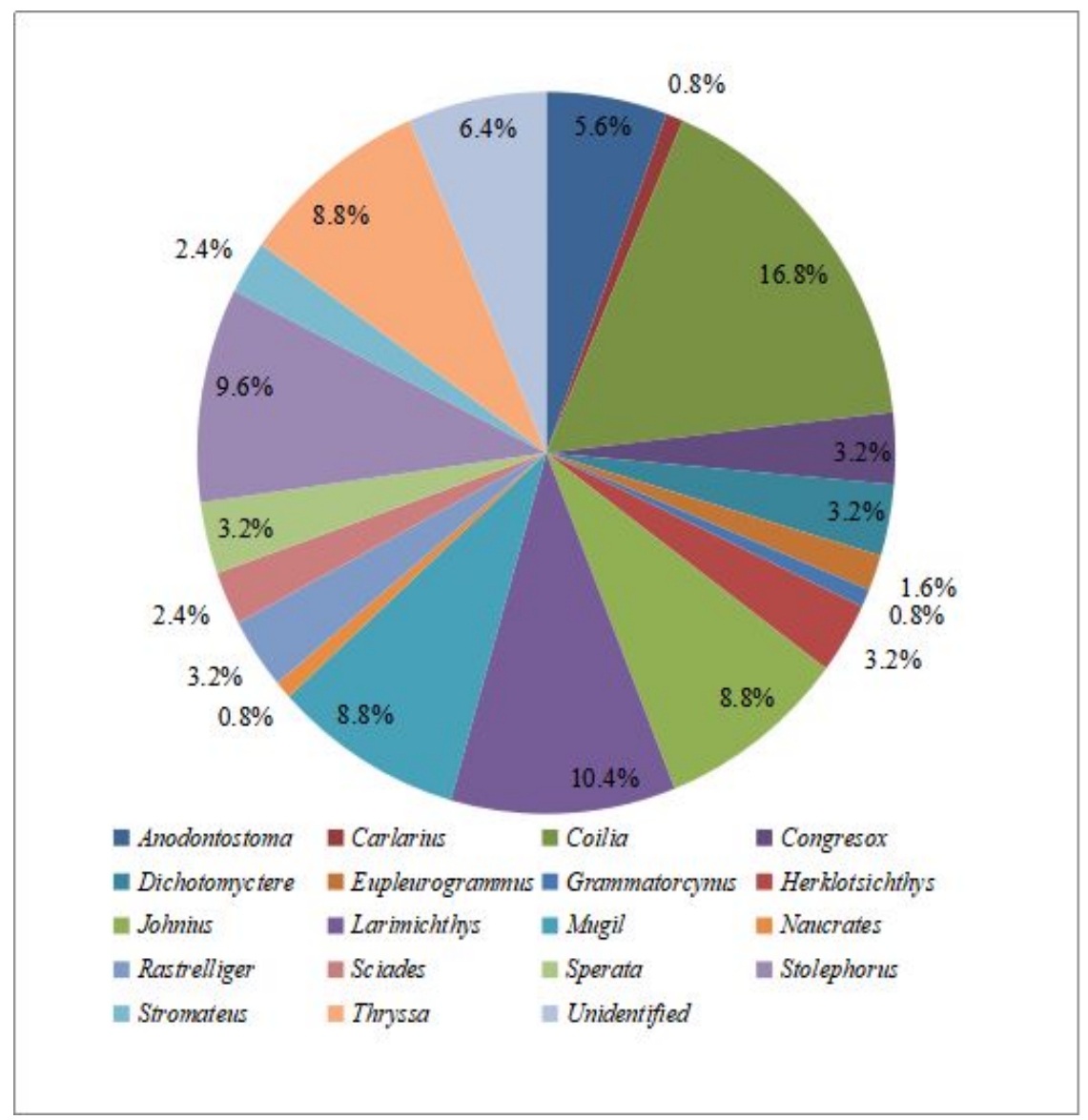

Gambar 4. Kelimpahan reatif genus ikan di perairan mangrove Desa Pasir 
perakaran mangrove $R$. Apiculata sehingga kemampuan predator berkurang untuk memangsa (Blaber, 2000; Laegdsgaard and Johnson, 2001; Mac-Donald et al., 2009; Nyanti et al., 2012).

Perbedaan jumlah jenis ikan yang tertangkap pada setiap stasiun disebabkan oleh perbedaan kondisi lingkungan seperti kerapatan mangrove dan aktivitas manusia. Mangrove dengan kerapatan yang tinggi memiliki keanekaragaman dan kelimpahan ikan yang tinggi (Odum 1983; Indriani et al., 2012; Sitorus et al., 2017). Hal ini terkait dengan adanya bahan organik dan detritus di ekosistem mangrove. Di lingkungan estuari, nutrisi merupakan komponen yang berperan penting untuk pertumbuhan, reproduksi dan metabolisme organisme (Hoque et al., 2015). Sejumlah nutrisi sangat penting bagi organisme akuatik seperti fitoplankton untuk pertumbuhan dan pembelahan sel (Spatharis et al., 2007; Saifullah et al., 2014), dimana fitoplankton berkontribusi pada rantai makanan (Hoque et al., 2015) di perairan yang dimanfaatkan oleh organisme akuatik seperti ikan di ekosistem tersebut. Selain itu, faktor lingkungan juga dapat mempengaruhi tingkat keanekaragaman ikan. Parameter lingkungan seperti suhu, $\mathrm{pH}$, salinitas, dan oksigen terlarut dapat mempengaruhi keanekaragaman, kelimpahan, persebaran dan komposisi jenis sumberdaya ikan (Blaber, 2000; Hoq and Islam, 2007; Chowdhury et al., 2010; Latupapua, 2011; Saifullah, 2012; Eddy, 2013; Saher et al., 2018).

Parameter lingkungan baik parameter fisika-kimia seperti suhu, salinitas, $\mathrm{pH}$, dan oksigen terlarut dapat mempengaruhi kehidupan organisme akuatik (ikan, udang, dan kerang) dan kehidupan vegetasi mangrove (Sitorus et al., 2017). Selain itu, Martino and Able (2003) dan Chowdhury et al. (2010) juga menyatakan bahwa faktor fisika, kimia, dan biologi dapat mempengaruhi kelimpahan sumberdaya ikan di ekosistem akuatik.

Faktor lain yang dapat mempengaruhi keanekaragaman dan kelimpahan ikan di ekosistem mangrove adalah aktifitas perkapalan. Semakin meningkat aktivitas perkapalan dapat menimbulkan tingkat kebisingan yang tinggi (Popper and Hasting, 2009). Pengaruh yang ditimbulkan tergantung pada intensitas aktifitas perkapalan tersebut. Dampak yang diberikan mulai dari tidak adanya perubahan tingkah laku ikan, pengaruh ringan, dan respon yang ekstrim (Wardle et al., 2001) sehingga menyebabkan pergerakan selama terjadinya kebisingan maupun perpindahan dari habitatnya (Slotte et al., 2004), baik perpindahan sementara ataupun perpindahan yang lama (Nyanti, 2014).

Hasil tangkapan ikan pada perairan mangrove Desa Pasir Kabupaten Mempawah memiliki variasi ukuran dari $6-46 \mathrm{~cm}$ dan memiliki jenis yang bervariasi. Hal tersebut berkaitan dengan fungsi ekologi mangrove yaitu sebagai area spawning ground, nursery ground, dan feeding ground bagi ikan (Nontji, 1987; Saputro et al., 2009; Nuitja, 2010; Kordi, 2012). Mahmudi (2010) juga mengatakan bahwa di ekosistem mangrove terdapat banyak detritus yang berperan sebagai pengurai serasah mangrove, yang mana serasah mangrove yaitu bahan utama yang dapat menenghasilkan nutrisi, dan plankton sebagai pakan alami untuk ikan. Ketersediaan nutrisi yang melimpah membuat ekosistem mangrove berbeda dengan ekosistem lainnya, dan merupakan tempat yang baik bagi sumberdaya perikanan untuk melakukan pemijahan dan pembiakan (Huxham et al., 2004). Hasil penelitian Nyanti et al. (2005) yang dilakukan di ekosistem mangrove Paloh, menemukan bahwa kelimpahan sumberdaya ikan (70 spesies) yang tinggi didukung oleh adanya detritus di lokasi tersebut.

Tabel 3. Keanekaragaman, keseragaman, dan dominansi di setiap stasiun

\begin{tabular}{ccccccc}
\hline Keterangan & St I & St II & St III & St IV & St V & Rata-rata \\
\hline $\mathrm{H}^{\prime}$ & 2,40 & 1,75 & 2,52 & 2,33 & 2,06 & 2,21 \\
$\mathrm{E}$ & 0,94 & 0,90 & 0,93 & 0,94 & 0,94 & 0,93 \\
$\mathrm{C}$ & 0,10 & 0,20 & 0,09 & 0,11 & 0,14 & 0,13 \\
\hline
\end{tabular}


Jenis ikan dengan jumlah tangkapan yang banyak di perairan Desa Pasir yaitu Coilia, Johnius, Larimichthys, Mugil, Stolephorus, dan Thryssa. Genus Coilia merupakan genus yang ditemukan dengan jumlah yang paling banyak (Gambar 3) dan dapat ditemukan pada semua stasiun pengambilan sampel di perairan mangrove Desa Pasir. Penelitian yang dilakukan oleh Mukherjee et al. (2012) dan Hoque et al. (2015) di perairan mangrove juga mendapatkan hasil bahwa genus Coilia ditemukan dominan di semua stasiun pengamatan dan pada semua musim. Dominansi genus Coilia disebabkan karena mereka memiliki toleransi yang tinggi terhadap faktor lingkungan dan ekosistem mangrove merupakan habitat yang cocok bagi genus tersebut sebagai nursery dan spawning ground (Singh, 2003).

Saher et al. (2018) menemukan Stoleporus indicus $(42,84 \%)$ dan Thryssa virirostris $(21,84 \%)$ sebagai spesies yang dominan dan ekonomis penting di Teluk Sonmiani. Hasil penelitian Hoq and Islam (2007), Sunarto (2008) dan Rizwan et al. (2017) menemukan Mugil cepalus sebagai spesies yang dominan. Ikan jenis Mullet (Valamugil speigleri) termasuk ikan penetap sementara di ekosistem mangrove selama fase juvenil dan ketika telah mencapai fase dewasa, mereka cenderung membentuk gerombolan di sepanjang daerah pesisir yang masih dekat dengan mengrove (Sihombing et al., 2017). Jenis ikan lain yang juga dapat ditemukan di perairan mangrove adalah Johnius (Hoque et al., 2015; Sitorus et al., 2017).

Faktor yang mempengaruhi jumlah hasil tangkapan pada suatu perairan adalah ketersediaan makanan dan tipe perairan. Stasiun ini berhadapan langsung dengan daerah wisata dan kanal sebagai akses keluar masuknya kapal, serta tergolong perairan pantai. Descasari et al. (2016), mengatakan bahwa daerah perairan muara dan pantai Desa Pabean Ilir memiliki hasil tangkapan yang tinggi terutama genus Johnius dan Ambassis. Hal tersebut dipengaruhi oleh ketersediaan makanan.

Famili yang dominan adalah Engraulidae $(35,2 \%)$, diikuti oleh Sciaenidae $(19,2 \%)$, Mugilidae (8,8\%), Clupeidae $(8,8 \%)$, Scombridae (4\%). Famili Ariidae, Bagridae, Muraenesocidae, Tetraodontidae memiliki persentase yang sama $(3,2 \%)$, Trichiuridae $(1,6 \%)$, Stromateidae $(2,4 \%)$, dan individu lainnya yang belum teridentifikasi sebanyak $(6,4 \%)$ (Gambar 4). Hasil penelitian
Ajazuddin et al. (2002) dan Hoque et al. (2015) juga menemukan ikan dari famili Engraulidae memiliki persentase paling tinggi selama penelitian.

Famili yang ditemukan pada penelitian di Desa Pasir ini merupakan famili yang secara umum ada di perairan ekosistem mangrove (Mukherjee et al., 2012; Nyanti et al., 2014; Hoque et al., 2015; Rizwan et al., 2017; Sihombing et al., 2017; Sitorus et al., 2017; Saher et al., 2018; Wahyudewantoro, 2018). Penelitian sebelumnya menemukan banyak spesies dari family Ariidae yang ada di perairan ekosistem mangrove merupakan biota laut pendatang (Sasekumar et al., 1994; Blaber, 1997; Nyanti et al., 2005).

Kelimpahan relatif setiap genus dapat dilihat pada gambar 4 Genus Coilia memiliki kelimpahan relatif tertinggi $(16,8 \%)$, genus ini merupakan satu-satunya genus yang dapat ditemukan pada semua stasiun pengambilan data. Genus yang memiliki kelimpahan relatif terendah adalah Naucrates, Grammatorcynus dan Carlarius (0,8\%). Dari semua genus yang diemukan, ada beberapa jenis ikan ekonomis penting seperti Rastrelliger, Mugil, dan Sperata. Kordi (2012), ikan-ikan ekonomis yang ditemukan di ekosistem mangrove adalah dari famili Siganidae, Lutjanidae, Mugilidae, Clupeidae, dan Carangidae.

Hasil penelitian Hoque et al. (2015) menemukan sumberdaya ikan dengan jumlah yang relatif besar termasuk spesies komersial penting. Di Indonesia, Rastrelliger kanagurta merupakan ikan air laut dan sebagai komoditas penting (Kunzmann and Braitmaier, 2018) serta memiliki nilai jual tinggi. Basavaraja et al. (2014), menemukan spesies Sperata oar juga merupakan spesies ikan ekonomis penting yang dapat dibudidayakan.

Tabel 2 menunjukkan indeks keanekaragaman, keseragaman, dan dominansi jenis ikan di perairan mangrove Desa Pasir. Nilai indeks keanekaragaman ( $\left.\mathrm{H}^{\prime}\right)$ berkisar antara 1,75-2,40 dengan nilai rata-rata sebesar 2,21. Indeks tertinggi terdapat pada stasiun III dan terendah pada stasiun II. Menurut Odum (1993), suatu perairan memiliki tingkat keanekaragaman rendah apabila nilai $\mathrm{H}^{\prime}<1$, keanekaragaman sedang apabila $\quad 1<\mathrm{H}^{\prime}<3, \quad$ dan keanekaragaman tinggi apabila $\mathrm{H}^{\prime}>3$. Berdasarkan kriteria tersebut, perairan mangrove Desa Pasir memiliki tingkat 
keanekaragaman jenis ikan masuk dalam kategori sedang.

Nilai indeks keseragaman (E) berkisar antara 0,90-0,94 dengan nilai rata-rata 0,93. Indeks tertinggi terdapat pada stasiun II dan terendah pada stasiun V. Menurut Odum (1993), apabila nilai indeks keseragaman mendekati 0 maka sebaran individu antar jenis tidak seragam dan terjadi dominansi, sedangkan nilai indeks keseragaman mendekai 1 maka sebaran individu antar jenis seragam dan tidak terjadi dominansi. Berdasarkan kriteria tersebut, perairan mangrove Desa Pasir memiliki sebaran individu antar jenis ikan yang seragam dan tidak terjadi dominansi.

Nilai indeks dominansi (D) berkisar antara $0,09-0,20$ dengan nilai rata-rata 0,13 . Indeks dominansi tertinggi adalah stasiun I dan terendah stasiun II. Menurut Odum (1993), suatu perairan memiliki tingkat dominansi rendah apabila nilai $\mathrm{C}<0,50$, dominansi sedang apabila nilai $0,50<\mathrm{C}<0,75$, dan dominansi tinggi apabila nilai $\mathrm{C}>0,75$. Berdasarkan kriteria tersebut, perairan mangrove Desa Pasir memiliki tingkat dominansi jenis ikan masuk dalam kategori rendah.

Perbedaan indeks keanekaragaman ikan pada perairan mangrove berkaitan dengan kerapatan vegetasi mangrove yang berbeda. Kerapatan vegetasi mangrove berpengaruh terhadap keanekaragaman jenis ikan di perairan sekitar ekosistem mangrove (Odum, 1993; Indriani et al., 2012).

\section{Kesimpulan}

Keanekaragaman jenis ikan di perairan Desa Pasir Kabupaten Mempawah dapat dipengaruhi oleh beberapa faktor, baik faktor alam seperti faktor hidrobiologi, maupun faktor non-alam seperti faktor aktifitas manusia yang dapat merubah tingkah laku ikan. Adapun kesimpulan yang didapatkan dari penelitian ini adalah:

1. Komposisi jenis ikan terdiri dari 12 famili dan 23 genus (teridentifikasi dan unidentified).

2. Famili yang paling banyak ditemukan adalah Engraulidae (35,2\%).

3. Genus yang memiliki kelimpahan relatif tertinggi adalah Coilia $(16,8 \%)$.

4. Perairan mangrove Desa Pasir memiliki tingkat keanekaragaman jenis sedang, seragam dan dominansi rendah.

5. Parameter fisika-kimia dalam rentang optimal yang dapat mendukung kelangsungan hidup oganisme akuatik kecuali oksigen terlarut, berdasarkan Standar kualitas air dari Kementerian Lingkungan Hidup No. 51 Tahun 2004.

\section{Daftar Pustaka}

Aburto-Oropeza, O.; Ezcurra, E.; Danemann, G.; Valdez, V.; Murray J.; Sala, E., 2008, Mangroves in the Gulf of California Increase Fishery Yields, Procedings of the National Academy of Sciences, 150(30):10456-10459.

Ajazuddin, S.; Ahmed, M., 2002, Some Observations On Occurrence And Abundance Of Finfishes In The Mianihor Lagoon, Baluchistan (Northern Arabian Sea, Pakistan), Pak. J. Zool, 34101-111.

Allen, J. H; Duvander J.; Kubiszewski I.; Ostrom E., 2012, Institutions for Managing Ecosystem Services, Solutions, 2(6):44-49.

Anneboina, L.R., and Kumar, K.S., 2017, Economic Analysis of Mangrove and Marine Fishery Linkages In India. Ecosyst Serv 24: 114123.

Balai Pengelolaan Sumberdaya Pesisir dan Laut, 2014, Refleksi Balai Pengelolaan Sumberdaya Pesisir dan Laut Pontianak Tahun 2009-2014, Pontianak. Kalimantan Barat.

Barbier E.B., 2000, Valuing the Environment as Input: Review of Aplications to Mangrovefishery Linkages, Ecological Economics, 35:47-61.

Barbier E.B., 2003, Habitat-Fishery Linkages and Mangrove Loss in Thailand,

Contemporary Economic Policy, 21:59-77.

Basavaraja, D.; Narayana, J.; Kiran, B.R., and Puttaiah, E.T., 2014, fish Diversity and Abundance in Relation to Water Quality of Anjanapura Reservoir, Karnataka, India, Int.J.Curr.Microbiol.App.Sci, 3(3): 747-757.

Blaber, S.J.M., 1997, Fish and Fisheries of Tropical Estuaries, Fish and Fisheries Series, Volume 22, London: Chapman and Hall. 367 pages.

Blaber, S.J.M., 2000, Tropical Estuarine Fishes: Ecology, Exploitation and Conservation, Oxford: Blackwell Science, 372 pages.

Blaber, S.J.M., 2000, Tropical Estuarine Fishes: Ecology, Exploitation and Conservation, Oxford: Blackwell Science, 372 pages.

Boyd C.E., 2000, Water Quality: An Introduction, Boston: Kluwer Academic Press, 330 pages.

Boyd C.E., 2000, Water Quality: An Introduction, Boston: Kluwer Academic Press, 330 pages.

Brahmana P., 2014, Ekologi Laut, Universitas Terbuka-Kementerian Pendidikan dan Kebudayaan, Banten, Indonesia.

Burhanudi, 2011, Perilaku Organisasional, Yogyakarta, CAPS.

Camp, A.L.; Ryer, C.H.; Laurel, B.; Seals, K., 2011, Effect of Nursery Habitat on Density-Dependent Habitat Selection in 
Juvenile Flat Fish, J Exp Mar Biol Ecol 404: 15-20.

Carpenter, K.E., V.H. Niem, 1999, FAO Species identification guide for fishery purposes. The living marine resources of the Western Central Pacific, Vol. 3, Batoid Fishes, Chimaeras and Bony Fishes part 1 (Elopidae to Linophrynidae).

Carpenter, K.E., V.H. Niem, 1999, FAO Species identification guide for fishery purposes, The Living Marine Resources of The Western Central Pacific, Vol. 4, Batoid Fishes part 2 (Mugilidae to Caragidae).

Carpenter, K.E., V.H. Niem, 1999, FAO Species identification guide for fishery purposes, The Living Marine Resources of The Western Central Pacific, Vol. 5, Bony Fishes Part 3 (Menidae to Pomacentridae).

Chowdhury, M.S., Hossain, N.G., 2010, Barua Environmental Variables and Fisheries Diversity of the Naaf River Estuary, Coast Conserv, 15: 163-180.

Costanza, R.; de Groot, R.; Sutton, P.; van der Ploeg, S.; Anderson, S.J.; Kubiszewski, I.; Farber, S.; Turner R.K., 2014, Changes in the Global Value of Ecosystem Services, Global Environ Change, 26:152-158.

Das S., 2017, Ecological restoration and livelihood: Contribution of

planted mangroves as nursery and habitat for artisanal and

commercial fishery, World Development, 94: 492-502.

Descasri R., Setyobudiandi I., Affandi R., 2016, Keterkaitan Ekosistem Mangrove dengan Keanekaragaman Ikan di Pabean Ilir dan Pagirikan Kabupaten Indramayu Jawa Barat, Departemen Manajemen Sumberdaya Perairan, Fakultas Perikanan dan Ilmu Kelautan, Institut Pertanian Bogor, Bogor.

Eddy S., 2013, Inventarisation and Identification of Fishes at Tidal Waters of Estuarin at Palembang, Research Institute of Lampung University, Lampung, 186.

Effendi H., 2003, Telaah Kualitas Air: Bagi Pengelolaan Sumberdaya dan Lingkungan Perairan, Kanisius, Yogyakarta.

Harahab N., 2009, The Infuence of Mangrove Ecosystem as Their Role for Catching Productivity (Case Study In Pasuruan Residence, East Java), Jurnal Perikanan, 11(1):100-106, in Indonesian.

Hoq, M.E. and Islam, M.N., 2007, Fish Fauna and Fisheries in the Coastal Waters of Similajau, Bintulu, Sarawak, Malaysia, Indian Journal Marine Sciences, Vol. 36 (3), pp. 206-215.

Hoq, M.E. and Islam, M.N., 2007, Fish Fauna and Fisheries in the Coastal Waters of Similajau, Bintulu, Sarawak, Malaysia, Indian Journal Marine Sciences, Vol. 36(3), pp. 206-215.
Hoque M.M.; Kamal A.H.M.; Idris M.H.; Ahmed O.H.; Hoque A.T.M.R.; Billah M.M., 2015, Litterfall Production In A Tropical Mangrove Of Sarawak, Malaysia, Zoology and Ecology, in press, doi: 10.1080/21658005.2015.1016758.

https://www.fishbase.de/ diakses pada tanggal 28 Oktober 2018, pada pukul 22:27 WIB.

Hutchison J.; Spalding M.; zu Ermgassen P., 2014, The Role of Mangroves in Fisheries Enhancement, The Nature Conservancy and Wetlands International, United Kingdom.

Huxham, M.; Kimani, E.; Augley, J., 2004, Mangrove Fish: A Comparison of Community Structure between Forested and Cleared Habitats, Estuarine, Coastal and Shelf Science, 60: 637-647.

Hwanhlem N.; Jean-Marc C.; Aran H.K., 2014, Bacteriocin-Producing Lactic Acid Bacteria Isolated from Mangrove Forests in Southern Thailand as Potential Bio-Control Agents in Food:Isolation, Screening And Optimization, Food Control, 41: 202-211.

Indriani, D.P.; Sagala, E.P.; Astri, L., 2012, Fish Diversity At Mangrove Forest Of Nypa Fruticans Wurmb At Banyuasin, South Sumatera, Sriwijaya University, Palembang, 68.

Islam M. S., Haque M., 2004, The Mangrove-Based Coastal and Nearshore Fisheries of Bangladesh: ecology, exploitation and management, Reviews in Fish Biology and Fisheries, 14:153-180.

Kamsari, 2015, Menyemai kehidupan mangrove, http://pkspl.ipb.ac.id/berita-menyemai-kehidu pan-dari-mangrove.html, Diakses pada jum'at 29-februari-2017 pada pukul 23:47. 